УДК 82-291.1"653"

DOI: $10.17223 / 19986645 / 59 / 15$

\title{
Н.Г. Юрина
}

\section{ТРАНСФОРМАЦИЯ ТРАДИЦИЙ СРЕДНЕВЕКОВОЙ МИСТЕРИИ В «БЕЛОЙ ЛИЛИИ» В.С. СОЛОВЬЁВА}

Анализируется трансформаџия традиций средневековой мистерии в пьесе В.С. Соловьёва «Белая Лилия» (1878-1880; 1893). Автор статьи исходит из убеждения, что мистериальная составляющая произведения воплощалась его создателем серьёзно, без элемента пародии, с учётом катарсических возможностей жанра, несмотря на обозначение «мистерия-иутка». Исследуя логику осмысления и усвоения традичий средневековой мистерии Соловьёвым, сопоставляя характерные для неё сюжеты, организацию образной системы, ключевые мотивы, композицию, язык, художественные приёмы с текстом «Белой Лилии», автор приходит к вывооу, что произведение содержит многие жанровые черты мистерии.

Ключевые слова: В.С. Соловьёв, драматургия, поэтика, мистерия-иутка, литературная традичия, юмор, образная система, композиция, тема, мотив.

Центральное место в драматургическом творчестве В.С. Соловьёва занимает мистерия-шутка «Белая Лилия, или Сон в ночь на Покрова». Особая значимость этого произведения для художественного наследии Соловьёва объясняется несколькими причинами. Во-первых, это его единственная многоактная драма, включающая три действия. Во-вторых, в «Белой Лилии» переплелись сокровенные авторские идеи, определившие суть его философской концепции, и поэтическая образность. В-третьих, текст традиционно воспринимается как парадоксальный, спорный по эстетическим достоинствам, в невыгодном свете представляющий его создателя, авторитетного религиозного мыслителя. Даже духовно близкие Соловьёву современники, считавшие себя его последователями, относились к «Белой Лилии» скептически. Для В.Л. Величко это произведение «мало понятное», с неясной жанровой принадлежностью: «комедия (?)» [1. С. 61]. Для Соловьёва-племянника «это очень странная пьеса», «шутки самые грубые, развязные и иногда циничные, крайняя нелепость и чепуха переплетаются в ней с... мистикой Софии» [2. С. 156]. С.Н. Булгаков характеризовал пьесу как «стихотворный фарс о Софии», «граничащий с мистической порнографией и вместе с тем включающий... вполне серьёзные... софийные стихотворения» [3. С. 81].

Важно и то, что первая редакция пьесы создавалась Соловьёвым в 1878-1880 гг., во время активных занятий «домашним» искусством, а её публикация состоялась только в 1893 г. Совершенно очевидно, что текст значительно дорабатывался: в окончательном варианте отсутствовал пролог, была иная система персонажей и сюжет, изменилось авторское жанро- 
вое обозначение - вместо «мистерии в трёх действиях с прологом» в подзаголовке появляется «мистерия-шутка». Создавал вторую редакцию уже не юноша, а зрелый человек со сложившимся мировоззрением и определёнными взглядами на задачи литературы, поэтическим багажом, возросшим художественным мастерством и стремлением к жанровому экспериментаторству.

Соловьёв воспринимал театр через религиозно-теургическую модель. Именно с драматургией он связывал воплощение своей мечты о преображении человека и мира средствами искусства. Очевидно, поэтому для своей ключевой пьесы драматург выбрал жанр мистерии, который не только предполагал постановку проблемы взаимоотношения человека с высшими силами, но и прямо ставил дидактические цели. Жанр мистерии позволил Соловьёву, с одной стороны, реализовать риторический, пророческий темперамент, открыть человечеству некие сакральные истины, с другой - приблизить современное искусство к теургическому, воздействовать на читателя средствами театра, показать то, что мешает двигаться по пути самосовершенствования. На наш взгляд, в своей художественной практике Соловьёв соединил жанровые возможности западноевропейской и отечественной мистерии XVII столетия. На русской почве этот жанр определялся спецификой духовного театра, призванного объединять в деле всеобщего покаяния и спасения, построенного по законам православной литургии (анонимный «Диалог про страдания Христовы», «Царство натуры людской...», «Рождественская драма», «Успенская драма» Дмитрия Ростовского). В западноевропейском варианте он имел (особенно на позднем этапе развития) синтетическую природу: был близок трагедии своим катарсическим очищением, но не исключал возможностей комедии, развлекающей и вместе с тем разоблачающей при помощи смеха недостатки действительности и человеческие пороки (немецкая мистерия о сошествии Иисуса Христа в ад (1464), английская мистерия рождественского цикла «Вифлеемские пастухи», сцена с женой Ноя в цикле «Таунлей», французская «Мистерия о святом Мартине», включающая фарс «Мельник, чью душу в ад чёрт уволок»). Соловьёв совместил в своём тексте высокий смысл русской литургической мистерии ${ }^{1}$ с поэтикой поздних западноевропейских образцов этого жара.

Обратим внимание на то, что процесс проникновения «низкого плана» в религиозную мистерию в отечественной литературе начался ещё до Соло-

\footnotetext{
${ }^{1}$ Современные соловьёвоведы всё более настойчиво соотносят художественное творчество В.С. Соловьёва с традициями древнерусской литературы. См., например: Черкасова E.A. Жанры средневековья в поэзии В.С. Соловьёва // Русский мир в духовном сознании народов России. Тюмень, 2008. С. 252-254; Ее же. Мистериальный сюжет в стихотворении В.С. Соловьёва «В тумане утреннем неверными шагами» // Соловьёвские исследования. 2012. № 3 (35). С. 81-92. Действительно, нельзя не учитывать, что в литературно-критических и публицистических работах Соловьёва явно выражен интерес к древней отечественной словесности, что как поэт он «оказался восприимчив к традиции жанров древнерусской литературы» [4. С. 143].
} 
вьёва. Этому способствовали, в частности, романтики, оказавшие, определяющее влияние на художественное творчество автора «Белой Лилии» (мистерия «Ижорский» В.К. Кюхельбекера, 1826-1841; мистерия в трёх периодах» «Жизнь чиновника» И.С. Аксакова, 1843). Однако произведение Соловьёва отличалось от мистерий русских романтиков тем, что «высокий план» в нём не вписывался в явно вымышленный, сказочный контекст, а прорисовывался с той степенью серьёзности, которая была характерна для литургических образцов жанра, «низкий» же план расширялся и углублялся настолько, что проникал в мистический. Можно лишь предположить, что подобное художественное решение было вызвано в том числе биографическими обстоятельствами: Соловьёв переживал период разочарования в своём теургическом проекте. В письме к Д.Н. Цертелеву в июле 1879 г. он писал, что ощущает «самые противоположные настроения», представляет «живой пример единства противоречий» [5. Т. 2. С. 249]. Вполне логично, что в этот период сомнений он выставил на всеобщее обсуждение собственную философскую концепцию в «Белой Лилии», придав своим идеям художественную форму и поместив их в смеховое поле (способ защиты или самоирония?).

Вопрос о соотношении «серьёзного» и «шуточного» в драматургическом творчестве Соловьёва был поставлен ещё его современниками, а в соловьёвоведении утвердился начиная с работ 3.Г. Минц и А.Ф. Лосева. Однако на практике две эти составляющие не всегда воспринимались как равноценные. Так, И.А. Аполлонская, анализируя «Белую Лилию» ${ }^{1}$, определяла её жанр как мистерию и не придавала большого значения смеховой стихии. 3.Г. Минц трактовала это произведение Соловьёва иначе: «В целом в пьесе явно преобладают тона иронические» [6. С. 51]. Исследователи драматургии Соловьёва 2000-х гг. изучали прежде всего смеховой компонент «Белой Лилии». И.Б. Роднянская уточнила жанровое обозначение пьесы: не «мистерия-шутка», но «мистерия-буфф» [7. С. 91], в которой господствует «юмор юродства» [Там же. С. 98], имея в виду, что смех вторгается здесь в повествование о вещах дорогих и даже священных для говорящего. Е.С. Шевченко обратила внимание на то, что творческая личность Соловьёва-драматурга сформировалась в среде «кружкового» искусства, атрибутами которого были игра, мистификация, театрализация быта и поведения. Неофициальная творческая среда, считает она, предопределила «присутствие черт балаганной народной комедии и поэзии нонсенса» [8. С. 16] в пьесах Соловьёва.

Показательно, что исследователи творчества В.С. Соловьёва единодушны в том, что грань между патетическим и смешным в поэзии была для него нечувствительной: он легко переходил от одного к другому. «...В серьёзном, - пишет И.Б. Роднянская, - у Соловьёва содержится очень часто

${ }^{1}$ В книге «Христианский театр» она рассматривала произведение как однозначно мистическую драму, предполагая в каждой шутке наличие высокого скрытого смысла (Аполлонская (Стравинская) И.А. Христианский театр. СПб., 1914. С. 57). 
сакральная крупица смеха - поэзии - свободы» [7. С. 88]. «“Белая Лилия” В. Соловьёва, - вторит ей Е.С. Шевченко, - постоянно балансирует на грани серьёзного и смешного, мистериального и буффонного. В сюжете пьесы сквозь бытовое, комическое просвечивает вселенское, мистериальное, и наоборот - мистерия каждый раз грозит обернуться балаганом» [8. С. 14]. Следовательно, для Соловьёва была близка поэтика западноевропейской средневековой мистерии, которой свойственно смешение серьёзного и комического, сакрального и карнавального. В отечественной литературе периода Средневековья существовало особое отношение к комическому. Как отмечал М.П. Одесский, «специфика древнерусской модели комического детерминирована тем, что оппозиция “серьёзное / смешное”, производна от базовой культурной оппозиции “Божественное / демоническое” (“норма / аномалия' ')... Бог, Божественное, эманация Божественного в мире нормативная сфера, сфера абсолютно серьёзного... смех выступает как аномалия, как атрибут дьявола... дьявол лишён способности творчества, он “обезьянничает”... заимствуя формы существования путём имитации или творчества наоборот...» [9. С. 110-111]. Как следствие - серьёзному в древнерусской литературе соответствовали «действительные жанры» [Там же. С. 112], а смешному - их имитация и пародирование. Смешное не уничтожало серьёзное, но сосуществовало с ним. Впрочем, уже к XVII столетию смеховая стихия проникла во многие жанры русской литературы, в том числе в драматургию (интермедия). Комическое охватило и «низкие» и «высокие» персонажи, и «низкое» и «высокое» слово, и «низкую» и «высокую» тематику. В самые серьёзные пьесы (например, в «Стефанотокос») включались шутовские сценки для развлечения зрителей, утомлённых длинным нравоучительным спектаклем. Использование «низких» персонажей и языка создавало пародию: выстраивалась дополнительная сюжетная линия, дублирующая «высокую»; тема в пределах произведения получала двойную аранжировку.

Мы будем исходить из того, что «Белая Лилия» Соловьёва в соответствии с традицией древнерусской мистерии воплощала мистериальное содержание вполне серьёзно, с учётом катарсических возможностей жанра. Буффонная же (шуточная) составляющая пьесы восходила к поэтике поздней западноевропейской мистерии. Трансформация мистериальных традиций в драматургическом творчестве Соловьёва происходила во многом с учётом опыта отечественной романтической мистерии ${ }^{1}$.

Мистериальное мировидение оказалось чрезвычайно близким Соловьёву именно к 1880-м гг., когда он обдумывал основные положения будущего трактата «Красота в природе». В Средневековье историческая эволюция понималась как осуществление воли Провидения. Для Соловьёва развитие

1 См. об этом: Юрина Н.Г. Традиции романтической мистерии в творчестве В.С. Соловьева («Ижорский» и «Белая Лилия»). Православие и русская литература : сб. науч. ст. / отв. ред. Б.С. Кондратьев. Арзамас : Арзамасский филиал ННГУ, 2016. C. $198-207$. 
природы также имело мистический смысл, трактовалось как последовательное движение от тьмы к просветлению, а жизнь человека - как странствие в поисках истины и высшей красоты. В первоначальном варианте «Белой Лилии» существование героев рассматривалось параллельно с дополнительным действом - борьбой за их души тёмных и светлых сил, что для жанра мистерии имело сюжетообразующее значение. В окончательном виде идею, систему персонажей, события определил «любовный» сюжет, прямо вытекающий из авторской философии любви («Смысл любви», 1892-1893), однако и после доработки мистериальный пласт, связанный с темой преобразующего воздействия высших сил на грешного человека, оставался существенным. И в начале 1890-х гг. жанр мистерии (в её духовной, литургической разновидности) оказался созвучным эстетической концепции Соловьёва. Он был убеждён, что под воздействием божественного вдохновения художник способен пересоздавать реальность, в которой существует. Следовательно, жизнь творца рассматривалась им в мистериальном контексте, а мистериальность трактовалась как определяющее качество истинного искусства. Конечно, мистериальный сюжет по сравнению со средневековой традицией существенно трансформировался у Соловьёва в соответствии с новой социокультурной ситуацией, авторскими философскими и эстетическими взглядами. Литургическая мистерия была связана с вопросом о пути человечества во Вселенной, Соловьёв поставил вопрос о судьбе самой Вселенной, о возможностях «восхождения» или, напротив, «вырождения» космоэволюционного процесса.

Религиозная (литургическая и полулитургическая) мистерия, один из жанров средневекового театра, определялась, как правило, сюжетом, взятым из Библии. Она показывала жизнь как некое онтологическое таинство, бесконечное движение к нравственным высотам, к новым уровням бытия благодаря осуществлению воли Провидения. Соловьёв отказался от библейского сюжета, связал основное действие «Белой Лилии» с очень важной для своей философской концепции идеей нисхождения Софии в мир и одухотворения ею человечества. Тем не менее дидактические задачи, соотносимые с целями и функциями средневековой мистерии (драматург должен был воспитывать зрителей, предлагая им идеальные образцы для подражания и показывая последствия дурных поступков на отрицательных примерах; вызвать сочувствие к невинно страдающим героям, вести к катарсису), ставились в пьесе сознательно и серьёзно. «Белая Лилия» стала для её создателя и своего рода откровением, и шутливым наставлением зрителей, и своеобразным вкладом в борьбу за одухотворение человека средствами искусства. Несмотря на значимость тематики (мистическое спасение человечества) и дидактическую установку, Соловьёв придал главной коллизии пьесы комедийный характер, чтобы глубже отразить в ней противоречия между уродством эмпирической жизни и высшим способом бытия. По его мнению, изобразить это было возможно, лишь показав недолжное комически, гиперболизировав несовершенства, противопоставив их идеалу. Об этом Соловьёв писал в посвящении к первому вари- 
анту пьесы: «Звучи же смех свободною волною, // Негодования не стоят наши дни. // Ты, муза бедная, над смутною стезёю // Явись хоть раз с улыбкой молодою // И злую жизнь насмешкою незлою // Хотя на миг один угомони» [10. С. 68].

Собственно мистерия начинает разворачиваться у Соловьёва уже в Прологе, оставшемся в черновиках и носящем эсхатологический характер. Русские литургические мистерии открывались именно прологом и аллегорическим антипрологом, в которых намечалось содержание предстоящего действия («Рождественская драма» Дмитрия Ростовского, 1702). Близкий приём использовал впоследствии и Соловьёв. Он вывел в Прологе «Белой Лилии» высшие силы - Бога (Геодемон), ангелов (лакеи Геодемона), демона (Китоврас, рождённый от тёмной ночи и хаоса). Большинство из них изображалось в сниженном, карикатурном виде: Геодемон - «в халате и в туфлях, на голове ночной колпак, а сверх него корона, в одной руке скипетр, а в другой - подушка» [Там же. С. 271], ангелы - «в синих и красных ливреях» [Там же. С. 269], с картонными крыльями. Внешнему виду героев соответствовала их авторская характеристика: Геодемон «весьма добродушен, иногда впадает в экстаз», ангелы «ленивы, надменны и глупы» [Там же]. Только «приказчик» Китоврас был лишён внешних комических черт, характеризовался сдержанно-положительно («распорядителен»), играл роль правдолюба, озвучивал идеи, которые разделял и сам автор: «По лицу земли // Лжи, убийства и разврата // Семена взошли» [Там же. С. 270]. Именно он объявлял о последнем дне бездуховного и безнравственного человечества. Когда Геодемон называет несколько имён «порядочных людей» - Мортамир, Халдей, Инструмент, Сорвал, Альконда, Теребинда, Галактея, Китоврас раскрывает безнравственную сущность их носителей и тем самым реализует традиционную функцию лица из пролога мистерии, дававшего характеристики основным действующим лицам. Тот факт, что из редакции 1893 г. Пролог был исключён, а функция характеристики главных персонажей и основного действия была передана столь же карикатурным, но всё-таки нейтральным лицам - Сокрушённому помещику, Скептику, Отчаянному поэту - объяснялся, видимо, причинами этического характера ${ }^{1}$. Герои-резонёры заменили проложных персонажей, которые вводили проблему развращённости человечества, общего кризиса жизни и необходимости спасения. Все они находились в «пороговой» ситуации, утратили смысл жизни, потеряли веру как опору существования. В их монологах звучали основные мотивы мистерии: непонимание природы иной жизни, отсутствие нравственных ориентиров, тоска по красивому и должному.

${ }^{1}$ Анализируя «Исторические картинки» К.К. Случевского, Соловьёв отмечал, что писатель, берущийся за религиозные темы, «обязан принимать меры предосторожности и против невольных грехов со своей стороны»: «Самая лучшая и общедоступная из предупредительных мер состоит здесь в том, чтобы вовсе не браться за такие темы, если не имеешь особого призвания и подготовки к этому делу и не смотришь на него как на главную задачу своей жизни» [11. С. 593]. 
Сюжеты в средневековой мистерии были статичными (действия не отличались разнообразием, повторялись) и имели зеркальную композицию изображались сходные, но контрастные по содержанию ситуации. На тех же принципах выстраивается и соловьёвская «Белая Лилия». Кавалер Мортемир (окончательное имя героя) слышит голос из «четвёртого измерения» и решает, по его совету, изменить свою жизнь и отправиться на поиски Белой Лилии. К нему присоединяются бросившие своих возлюбленных Халдей, Инструмент, Сорвал. Однако только Мортемир прозревает Белую Лилию в образе медведя, который встречается на их пути, и остаётся с ней. После смерти медведя Белая Лилия обретает свой истинный облик и уводит героя в «четвёртое измерение». Остальные соединяются с бывшими возлюбленными, увидев их другими глазами и испытав к ним истинную любовь. С одной стороны, в этом сюжете повторяются противоположно направленные эпизоды (встреча трёх пар возлюбленных, их разрыв и финальная сцена с примирением), с другой стороны, контрастно воспроизводятся любовные линии Мортемира - Белой Лилии и их последователей. По сравнению с первоначальным вариантом пьесы отредактированный сюжет был выстроен строже, в нём снимались некоторые двусмысленности в отношении религиозных предметов (самоубийство Мортамира на могиле медведя, колдовство Сатаны, о котором упоминала Белая Лилия, смерть возлюбленных от излишнего блаженства после соединения, благословление трёх пар на распространение по всей земле наслаждения любви). Авторская философская концепция Вечной Женственности воплотилась теперь более развёрнуто и точно. Мистериальный пласт сократился, на первый план выступил бытовой. Шуточные сцены стали прописываться гораздо тоньше.

Ключевыми в «Белой Лилии» становятся мотивы одухотворения и спасения человека любовью, преображения мира, перехода «отсюда» (из области повседневной действительности) «туда» (в мир истинных ценностей) и, наоборот, зова из иного мира. Эти мотивы, характерные для литургической мистерии, во многом определили и образную систему, и композицию произведения, и его поэтику. Из ключевых мотивов пьесы также важен мотив сна, восходящий и к романтической интерпретации мира и жизни, и к мистериальной их трактовке. Средневековый театр напоминал зрителю о том, что человек - игрушка высших сил, что его существование недолговечно: «Не бойся, честный внук Аврамов, // Лучши твой есть сон, нежели Адамов, // Спящу бо тому ребро отворися, // Жена родися; // Тебе же спящу отверзеся небо, // И восод готов ко небеси, се бо // Лествица с земли до небес досязает, // Ко Богу дерзает» («Успенская драма» Дмитрия Ростовского, конец XVII в.) [12]. Часто в средневековой драме беспрестанно меняющийся мир, идеальная жизнь показывались как ускользающие от человека (они - сон). В этой связи вещий сон становился необходимым компонентом для её поэтики: через сны предсказывалось будущее, открывались принципы истинной жизни, которая порой значительно отличалась от реальной. В «Страшном изображении второго пришествия», например, 
показывалось сразу два таких сна - Навуходоносора и пророка Даниила, предсказывающего будущее. В соловьёвской пьесе мотив сна имел определяющее значение. Автор, утверждая идею торжества нетленной красоты, использовал подзаголовок: «Сон в ночь на Покрова». По народным поверьям, всякое прошение на Покров должно исполниться, а сны накануне этого праздника обязательно сбываются. Таким образом, Соловьёв придавал повествованию символический смысл: его «Белая Лилия» - это сонмечта о рождении из очищенной материи высшей духовной красоты.

Поэтика мистерии основывалась на убеждении, что ни одно явление мира не существует изолированно, но всегда находится в отношении противопоставления с другими явлениями и с самим собой. Так, уже в антипрологе «Рождественской драмы» Дмитрия Ростовского поочерёдно выступают Натура людская и Натура, Век золотой и Век железный, Любовь и Ненависть, Незлобие и Ярость, Жизнь и Смерть, в его же «Успенской драме» - Ангел с небом и Ангел с землёю и т.д. Для Соловьёва-писателя эта антиномичность мышления была характерна. Это обстоятельство, наряду с мистицизмом вообще, очевидно, должно было привлечь его внимание к мистерии. Определяющим для жанра в его классическом виде было выстраивание сюжета на основе семантических оппозиций: верх - низ, свет тьма, красота - безобразие, внутреннее - внешнее, добро - зло, Бог - дьявол, Бог - человек. Мир как таковой делился на две части, каждый элемент одной имел антипод в другой. Все понятия приобретали и положительное и отрицательное значение, вступали в противоречие со своими антиподами. Строение мироздания проецировалось на сущность человека. Он рвался душой ввысь и был привязан к земле тяжестью плотской телесной оболочки, постоянно колебался от добра ко злу. Автор «Белой Лилии» также всё время подчёркивал единство земного и небесного, прекрасного и безобразного, глубоко духовного и ничтожного, нравственного и безнравственного в мироздании и человеческом характере. Его герои (особенно второстепенные) постоянно колеблются между двумя противоречивыми началами, что приводит к их внутренним изменениям. Путь главного героя, Мортемира, выглядит как более цельный. Но ведь и полоса его заблуждений была более широкой, а сами они - более глубокими. Кроме прожигания своей жизни в Петербурге, он был явно преступен в любовных отношениях. В черновом варианте второго действия он называл своих спутников «невинными щенятами» утверждал, что «...триста, 49000 женщин // Любил зараз» [10. С. 282]. Голос из четвёртого измерения, который слышит только Мортемир, упрекает его в том, что он «забыл Бога», называет «извергом» [Там же. С. 227]. Очевидно, что перелом в его сознании должен был быть кардинальным, ведь теперь он оказался ведом по жизни не только любовью, но и убеждением в необходимости очиститься страданием: «Венец терновый // Нужно стяжать» [Там же. С. 246]. Все герои пьесы (и прежде всего Мортемир) выступают как странники, ищущие себя и своего места в жизни, состоят в близком родстве с мистериальным персонажем, заблудившимся в лабиринте мира. Как и в средневековой драме, 
статус героев в структуре действия пьесы часто выравнивается, а их судьба зависит не только от личных качеств и душевных порывов, но и от внешней Божественной субстанции, одинаково довлеющей над каждым. Так, во французском миракле «Чудо о Теофиле» Рютбёфа главный герой, продавший душу дьяволу, всё-таки получает покровительство Мадонны. У Соловьёва грешника Мортемира выводит к свету Белая Лилия-София.

Герой средневековой духовной драмы являлся фигурой условной, носителем определённой идеи, и именно в этом качестве он «нёс большую сюжетообразующую и семантическую нагрузку» [13. С. 137]. Персонажи пьесы Соловьёва также условны. Даже главный из них - Мортемир - однозначен: это искатель идеала, рыцарь ${ }^{1}$ и певец Вечной Женственности. Несмотря на двойственность его имени ${ }^{2}$, это, безусловно, избранный, призванный совершить космическую миссию, соединить земное с вечным и повести за собой человечество. Именно ему адресован таинственный свиток из Тибета, символизирующий высшее знание. Конечно, герой несколько компрометируется ироническим обыгрыванием его «донжуанства». Вместе с тем этот его порок мог иметь для Соловьёва и серьёзное философское обоснование. В «Софии», произведении, созданном буквально за два года до начала работы над «Белой Лилией», рассуждая о характере любви, он писал: «...любовь, чтобы быть полной, должна быть двойной, также как <органический> союз по меньшей мере тройствен. Каждое существо связано любовью с двумя существами: одно оно любит восходящей любовью, а другое - любовью нисходящей. Но так как... совершенное существо единственно, то предметы нисходящей любви всегда более многочисленны, чем предметы любви восходящей. Высший предмет последней единствен - это София. Она находится в прямой связи с избранниками человечества (с необходимостью, мужчинами, ибо она женщина), которые любят её восходящей любовью и любимы ею любовью нисходящей. Они, в свою очередь, находятся в непосредственной связи с большим количеством индивидов (с необходимостью, женщин), которые любят их восходящей любовью, а они их любят любовью нисходящей; эти индивиды снова есть предмет восходящей любви для определённого количества индивидов-мужчин и так далее» [15]. В свете этих суждений образ Мортемира получает дополнительный ореол единственного избранника, «великого жреца человечества». Его любовные похождения становятся обоснованными идеей нисходящей любви. Впрочем, могла быть здесь и самоирония по поводу своих недавних, но уже пересмотренных идей.

Первоначально Мортемир очень неустойчив в решении поиска высшей любви: прощаясь с Галатеей, он, кажется, не прочь остаться: «В моей ду-

\footnotetext{
${ }^{1}$ И. Роднянская справедливо видит в нём «искателя Грааля, сосуда благодати в вечно-женственной его версии» [7. С. 100].

${ }^{2}$ О.А. Дашевская подчёркивает, что «морте» (с лат. «смерть») актуализирует два смысла: «победитель смерти» и представитель «земного, “мёртвого” мира» [14. С. 63]. Разрыв героя с прежним образом жизни указывает на первое значение, а комический ореол, сопровождающий его, - на второе.
} 
ше, поблёкшей и усталой, // Ты новые огни привыкла возбуждать (Хочет обнять её.)» [10. С. 226]. Только голос из «четвёртого измерения» настраивает его решительно. Эта смеховая составляющая образа главного персонажа снижает впечатление от его высокопатетических монологов о любви, взятых из «серьёзной» лирики Соловьёва. Они обретают двусмысленное звучание и противоречиво характеризуют героя. Дискредитация образа Мортемира достигается и за счёт бытовых подробностей: он чрезмерно заботится о своём внешнем виде («Но где моя дорожная фуражка? // Здесь! И перчатки в ней» [Там же. С. 229]), выезжает на поиски Белой Лилии «в дорожном платье и с чемоданом в руках» [Там же. С. 224], не гнушается хорошей закуской и выпивкой (авторская ремарка: «изрядно выпив и закусив» [Там же. С. 246]), периодически принимает эффектные позы («в позе отчаяния стоит кавалер де Мортемир» [Там же. С. 249]). Всё это свидетельствуют о том, что герой сильно погружён в мир земного существования, его душе трудно оторваться от привычных вещей.

В соловьёвоведении нет единого мнения о природе образа Белой Лилии. Конечно, трудно оспорить тот факт, что сама идея Вечной Женственности, ключевая для философии Соловьёва, претерпевает в пьесе ироническое снижение ${ }^{1}$. Она низведена до гротескного образа женщины, возникшей из тела медведя. Однако нельзя забывать, что Белая Лилия переживает и существенные обратные метаморфозы: снизойдя в земной мир в животном образе, она обретает свою истинную небесную сущность, переходит в «четвёртое измерение». Таким образом, идея восстанавливается в своих правах. Белая Лилия выполняет свою миссию - становится связующим звеном между вещественным и духовным мирами, способствует усовершенствованию человека и земного бытия.

По мнению И.Б. Роднянской, Белая Лилия - это воплощение одновременно и Софии, Премудрости Божьей, спасающей человечество, и падшей Души мира, которая сама нуждается в спасении. Это олицетворение и восходящей и нисходящей любви, так как кавалер де Мортемир одновременно и искатель высшего женского идеала, и создатель его силами земной любви [7. С. 99-100]2. В тексте пьесы, действительно, нет пояснения природы Белой Лилии. Это воплощение и истинной любви, и Божественной силы, невидимой для людей, и «таинство натуры», и женская сущность с «небес-

\footnotetext{
${ }^{1}$ Ироничность по отношению к «вечной Подруге», так возмутившая в своё время современников философа, была объяснима отчасти культурным контекстом - «кружковое» искусство было сориентировано на развлекательность, нестандартность и эпатажность. Вместе с тем нельзя не учитывать, что пьеса была пародией на всё, показывала многообразие форм природной и человеческой жизни, ощутимо удалённых от идеала.

${ }^{2}$ На наш взгляд, в пьесе Соловьёва действительно актуален мифологический контекст, связанный с образом Пигмалиона, идеей мужского «оформляющего» начала ми$\mathrm{pa}$, но он соотносится исключительно с линией Галактеи, последней земной возлюбленной Мортемира, которую он бросает непреображённой. Белая Лилия же перевоплощается не благодаря усилиям героя, который даже не вполне осознаёт её высокой сущности, а за пределом земной жизненной черты, на что Мортемир повлиять не мог.
} 
ными чертами», и «царица», и цветок. Каждая из этих характеристик дополняет, но не проясняет её образ и не может быть определяющей. Конечно, связь Белой Лилии с Премудростью Божией, Душой Мира из философских трудов и Вечной Женственностью из поэмы «Три свидания» отрицать нельзя, но этот образ, на наш взгляд, имеет и другие значения. В контексте шуточной мистерии он - и символ несовершенства, непроницательности человечества, которое может воспринимать Небесное только в грубо материальном, земном облике (человек, по логике пьесы, сам имеет «медвежью» натуру), и общечеловеческая идея, которую каждый воспринимает в меру своего интеллекта и эстетического чувства. Интересно, что образ Премудрости Божьей встречается уже в русской драматургии начала XVIII в. и присутствует, например, в небольшой анонимной пьесе без заглавия, которую впервые опубликовал В.И. Резанов ${ }^{1}$. Русские средневековые авторы, как правило, не выводили на сцену высшие сущности в собственном лице, зато в действии могли участвовать аллегорические фигуры неясной природы - «Всемогущая Сила», «Вражда» и др. Соловьёв также показал на сцене Вечную Женственность в её истинном виде лишь мнгновение, как дух, поднимающийся над могилой и сразу же переходящий в «четвёртое измерение».

Второстепенные персонажи обрисованы Соловьёвым в духе древних мистерий. В средневековой духовной драме всё имело особую семантическую нагрузку, в ней не было «фоновых» компонентов. Каждый из героев занимал своё место в художественном пространстве. Так, пастыри Борис, Авраам, Афоня из «Рождественской драмы» Дмитрия Ростовского равно значимы, абстрактные и аллегорические образы (Ангел, Вражда, Милость Божия и др.) наравне с конкретными участвуют в организации и продвижении действия. Всё, что воспроизводилось на сцене в пьесе Соловьёва, также имело высший смысл, который слагался из действий и речей всех актёров, общей композиции и отдельных эпизодов, деталей. Каждый из компонентов содержал частный оттенок идеи всей пьесы: истинная любовь даёт возможность одухотворения и спасения человечества. В традициях жанра часть действующих лиц в пьесе не названа даже именами собственными (Инструмент, Неплюй-на-стол, Скептик, Сокрушённый помещик, Отчаянный поэт). Их характеры схематичны, а действия и речи условны. Все они развивают свою «подтему» (каждый воплощает «животный» уровень сознания, человеческий порок - глупость, лень, обжорство и т.д.) и намеренно «смонтированы» из разных исторических эпох, культурных и национальных пластов. Три пары, идущие за Мортемиром, обозначают человечество, духовно несовершенное и греховное, но всё-таки стремящееся к идеалу, имеющее потенциал для внутреннего изменения. Все эти герои аллегоричны. Если Мортемир и Белая Лилия выступают связующими звеньями между конкретным и условным мирами, то они разрушают гра-

${ }^{1}$ См.: Резанов В.И. Из истории русской драмы: Школьные действа XVII-XVIIII веков и театр иезуитов. М., 1910. С. 249. 
ницы между ними. Аллегорическое действие развивается параллельно с основным, оттеняет его высокий смысл. В список действующих лиц, в соответствии с традицией средневековой духовной драмы, наравне с людьми внесены Птицы, Растения, Солнце, Совы, Волк, Львы и Тигры, Медведь и даже Голос из «четвёртого измерения».

Самым противоречивым второстепенным персонажем является «служитель науки из наук» Неплюй-на-стол. Несмотря на то, что он, хранитель древнего пергамента, содержащего великую тайну, указывает на «иной» путь, разъясняет природу Белой Лилии, созывает попутчиков Мортемиру, именно Неплюй-на-стол то и дело прерывает поиски предложением отобедать и так и не достигает цели, умирая от «гнусной» болезни. Можно предположить, что это пародийное воплощение, с одной стороны, учёного, ведомого по жизни чистым разумом, а не сердцем, закрытого для высоких чувств (у него единственного из странников нет земной пары), с другой стороны, чисто буффонный персонаж, неспособный к просветлению, наслаждающийся своим земным несовершенством. Однако именно Неплюй-на-стол, человек с именем, подчёркивающим его гастрономический фанатизм, видит то, что другие герои пока не прозревают: пещеру, где скрывается Медведь, он называет дворцом, ему мерещатся огни, фрейлины и придворные Белой Лилии. Правда, после общего возмущения он признаёт, что «пошутил немного».

Соловьёв уже в первом варианте текста помещает своего героя в пространственно-временное поле мистерии: близость «четвёртого измерения», действие всей пьесы «в местах, не столь отдалённых», наконец, параллельность пространств (на земле и «на облаках») и условность времени (от древнейших времен, когда высшие силы определяют события на земле, до эпохи «четвёртого измерения, где времени уже нет). Рамки будущего повествования раскрываются предельно широко: местом действия становится весь мир, действующим героем - человечество. Эта особенность проявляется и в окончательном варианте произведения, хотя автор, казалось бы, теперь стремится к уточнению, большей конкретизации места действия. Воссоздаётся бытовая и отчасти историческая обстановка. Исходная точка отсчёта - Петербург XIX в. Даны отдельные детали исторической и бытовой обстановки. Очевидно, перед нами российская действительность и публика высшего света - землевладельцы (граф Многоблюдов, кавалер де Мортемир), служащие различных департаментов и министерств (Халдей, Скептик), военные (генерал Хлестаков, отставной драгун Инструмент). Узнаваемы отдельные черты эпохи: одежда мужчин и дам, предметы. Мортемир устраивает бал в своём Зимнем саду в Петербурге; его поведение во многом определяется его социальной принадлежностью, историческими обстоятельствами. Однако второе действие переносится в «неизвестный лес», третье происходит «близ южного Тибета» [10. С. 215]. И здесь уже детали становятся размытыми, лишёнными конкретики: «ночной костюм» Сорвала и посох Неплюя-на-стол, водка и бордо на столе у путешественников, пергамент, пещера, шпаги в руках Халдея и Инстру- 
мента, кинжал Мортемира. Даже упоминания о Калуге и Чукотке не вносят пространственно-временной ясности. Между сценами проходят недели. Завершается действо переходом героев в иное измерение. Несмотря на то, что Соловьёв в конечном счете отказывается от воспроизведения развёрнутых действий в «четвёртом измерении», что, кстати, было характерно и для русской литургической мистерии (в западноевропейской духовной драме всё действие могло разворачиваться в раю - французское «Действо об Адаме»), пространственная организация в его пьесе всё-таки сохраняет иерархическую структуру, направленную не только по горизонтали, но и по вертикали. Правда, в отличие от средневековых пьес, где сцена была трехъярусной - рай, мироздание, ад, у Соловьёва она всё-таки на порядок меньше . Но его герои также свободно двигаются по вертикали: сверху вниз и снизу вверх.

Несмотря на буффонные тона, которые определяют целые сцены «Белой Лилии», особенно в первом её варианте, произведение в целом имеет шуточный, юмористический характер (и это подчёркнуто в авторском жанровом обозначении). Природа соловьёвского смеха родственна романтическому юмору, сущность которого очень точно определил В.К. Кюхельбекер: «...Humour не есть просто насмешливость, не есть одно остроумие, не есть vis comica без всякой примести; Humour не выражается исключительно ни сатирою, ни ирониею; насмешник, остряк, комик холодны... сатирик-саркастик ограничивается чувством гнева, негодования. Юморист, напротив, доступен для всех возможных чувств, он играет ими... юморист забавляется чувствами и даже над чувствами... как добрый старик забавляется с детьми...» [16. С. 751]. Юмор Соловьёва не холоден, не сосредоточен на обличении. Это смех свободный и лёгкий, иногда увлекающийся, но никогда не вырывающийся из-под надзора автора, который ведёт свою игру. В поэзии Соловьёва «разнообразные оттенки комического... это отражение его художественного миропонимания и литературной позиции в целом» [17. С. 39]. В «Белой Лилии» смех порой доходит до буффонадного гиперболизирования и шутовского на разных уровнях (расстановка образов, характер взаимоотношений трёх пар возлюбленных, балаганные похороны и свадьбы, иронический комментарий метаморфоз, происходящих с героями, травестирование собственных идеалов (Вечная Женственность в образе Медведя), пропуск второго явления в третьем действии как отражение мгновенности преображений, частая немотивированность поступков, сцены неузнавания героев в их истинном виде, балаганность поз, утверждение гармонии посредством «галиматьи», двусмысленность финала и т. д.). Но именно смех такого рода был единственной возможностью драмы указать на противоречия между высшим бытием и уродливой реальной действительностью, на бездуховность человека,

\footnotetext{
${ }^{1}$ Отсутствует пространственное обозначение ада. Возможно, это можно объяснить скептическим отношением Соловьёва к «гнусному догмату» [7. С. 97] о вечности адских мук.
} 
вполне довольного собой и положением вещей. Нельзя не учитывать и то обстоятельство, что поэтика буффонады и нонсенса использовалась автором прежде всего для изображения второстепенных персонажей, подчёркивала слабость благих намерений человечества на пути духовного обновления. Напротив, главный герой, Мортемир, несмотря на ироническую окрашенность этого образа, всё-таки завершает свою миссию: он показывает «сверхчеловеческий $n y m b$, которым шли, идут и будут идти многие, на благо всех» [18. С. 277]. Его шуточная трактовка была необходима, вопервых, в связи с убеждением Соловьёва в том, что человеческая природа всё-таки крайне далека от совершенства (идеальный герой мог бы невольно стать пародией на сокровенные христианские идеи): во-вторых, вследствие поэтики текста, в целом опирающейся на вариант поздней западноевропейской мистерии.

На языковом уровне для средневековой духовной драмы, в том числе русской, было характерно комическое многоязычие («высокая» часть языка содержала сакральный смысл, «низкая» (профанная речь (разговорная, диалектная, жаргонная) и «чужая» (тарабарский язык, основанный на звукоподражании) отражала обстоятельства действительности). Дмитрий Ростовский в «Рождественской драме» достигал комического эффекта, вводя иноземцев, говорящих на ломаном языке, с забавным акцентом, что подчёркивало низкую природу героев. «Низким» языком говорят у него и пастыри, пришедшие к вертепу: «здеся», «не замай спит», «чаю», «гето ты заблудил», «не фслухал» и т. д. Речь персонажей Соловьёва также сочетает «высокий» и «низкий» язык. Она непредсказуема, алогична, изобилует каламбурами, построенными на полисемии, омонимии или фонетическом подобии слов. Это отражает «галиматью» и «нелепицу» сознания, является способом характеристики персонажа: «Теребинда. Ха-ха-ха! Разве вы патагонец? Инструмент (отирая лицо платком). Сущий потогонец, как видите-с» [10. С. 220]. Для той же цели использовались буффонные приёмы, широко применяемые в средневековых интермедиях. В одном из «междуречий», опубликованных Н.С. Тихонравовым, Старику, желавшему постичь науки, в прямом смысле «острят» голову, так отвлечённое понятие «вострить разум» обыгрывается как конкретное. У Соловьёва близкой является сцена поглощения башмака возлюбленной, натуралистически иллюстрирующая слова Сорвала «моя любовь требует пищи». Использовал автор и приёмы иноязычных вкраплений, самохарактеристики героя, ситуации «неслышанья» персонажами друг друга, символизацию.

Таким образом, жанр средневековой мистерии был востребован в драматургическом творчестве В.С. Соловьёва. При реализации мистериального содержания автор «Белой Лилии» был ближе традициям русской литургической мистерии. Шуточная составляющая этого произведения восходила в большей степени к поэтике поздней западноевропейской мистерии. Вместе с тем и идейное содержание, и поэтика средневековой мистерии трансформировались в «Белой Лилии» в соответствии с эстетическими и художественными принципами эпохи, философскими и литературными 
взглядами автора. Соловьёв выступил экспериментатором в области драматургии, переосмыслившим традиции старого жанра, считающегося на данном временном этапе малопродуктивным и неактуальным.

\section{Лumepamypa}

1. Величко В.Л. Владимир Соловьёв: Жизнь и творения // Книга о Владимире Соловьёве. М., 1991. С. 12-76.

2. Соловьёв С.М. Владимир Соловьёв: Жизнь и творческая эволюции. М. : Республика, $1997.431 \mathrm{c}$.

3. Булгаков С.Н. Владимир Соловьёв и Анна Шмидт // Булгаков С.Н. Тихие думы. M., 1996. C. 51-82.

4. Юрина Н.Г. Переосмысление традиций жанров древнерусской литературы в поэзии В.С. Соловьёва // Вестник Томского государственного университета. Филология. 2014. № 4 (30). С. 135-145.

5. Письма Владимира Сергеевича Соловьёва / под ред. Э.Л. Радлова. СПб. : Общественная польза, 1909. Т. 2. 369 с.

6. Минц 3.Г. Владимир Соловьёв - поэт // Соловьёв В.С. Стихотворения и шуточные пьесы. Л., 1974. С. 5-56.

7. Роднянская И. «Белая Лилия» как образец мистерии-буфф // Вопросы литературы. 2002. № 3. С. 86-102.

8. Шевченко Е.С. Эстетика балагана в русской драматургии 1900-х - 1930-х годов: автореф. дис. ... д-ра филол. наук. Самара, 2010. 40 с.

9. Одесский М.П. Поэтика русской драмы: вторая половина XVII - первая треть XVIII в. М. : РГГУ, 2004. 397 c.

10. Соловьёв В.С. Стихотворения и шуточные пьесы. Л. : Сов. писатель, 1974. 352 с.

11. Соловьев В.С. Разбор книги г. К. Случевского // Соловьёв В.С. Философия искусства и литературная критика. М., 1991. С. 583-605.

12. Ростовский Д. Успенская драма. URL: http:/static.my-shop.ru/product/pdf/ 127/1260535.pdf (дата обращения: 01.03.2018).

13. Юрина Н.Г. История древнерусской литературы. Саранск : Изд-во Мордов. унта, 2010. $228 \mathrm{c}$.

14. Дашевская О.A. «Белая Лилия» Соловьёва как мистерия спасения: к вопросу об истоках «мистериального сюжета» в литературе первой половины XX века // Судьба жанра в литературном процессе / под ред. С.А. Ташлыкова. Иркутск, 2005. С. 62-74.

15. Соловьёв B.C. София. URL: http://mirosvet.narod.ru/sol/sofl.htm (дата обращения: 28.07.2016).

16. Королёва Н.В. Комментарий // Кюхельбекер В.К. Избр. произв. : в 2 т. / гл. ред. В.Н. Орлов. М. ; Л., 1967. Т. 2. С. 730-759.

17. Юрина Н.Г. Жанровый состав шуточной лирики В.С. Соловьёва // Вестник Ленинградского государственного университета им. А.С. Пушкина. 2014. № 1, т. 1: Филология. С. 30-39.

18. Соловьёв В.С. Лермонтов // Соловьёв В.С. Литературная критика. М., 1990. C. 274-291.

\section{Transformation of the Traditions of the Medieval Mystery Play in Vladimir Solovyov's} The White Lily

Vestnik Tomskogo gosudarstvennogo universiteta. Filologiya - Tomsk State University Journal of Philology. 2019. 59. 243-59. DOI: 10.17223/19986645/59/15

Natalya G. Yurina, Ogarev Mordovia State University (Saransk, Russian Federation). E-mail: makarova-ng@yandex.ru

Keywords: Vladimir Solovyov, dramatic art, poetics, mystery-joke, genre, literary tradition, humor, imagery, composition, theme, motive. 
The article analyses the transformation of the traditions of the medieval mystery play in the play The White Lily by Vladimir Solovyov. The analysis of the text confirms that Solovyov presented the mystery component of the work in accordance with the tradition of the Russian liturgical mystery ("Christmas Drama" by Dmitry Rostovsky, etc.), quite seriously, without parodying, taking into account the catharsic possibilities of the genre, despite its designation as a "mystery-joke". The buffoon (comic) part of the play goes back to the poetics of the late West European mystery (the French The Mystery of Saint Martin with The Farce of The Miller Whose Soul The Devil Carries To Hell, etc.).

Traditions of the medieval mystery play are seen in The White Lily at the level of the plot, the organization of the figurative system, key motifs, composition, language, and artistic techniques.

In the original version of The White Lily, the characters' existence was considered through the prism of the struggle for their souls between the dark and light forces, which was a plotforming feature for the mystery play as a genre. In the final form, the idea, the system of characters and individual turns of action were determined by the "love" line, but, even after the completion, the mysterious layer associated with the theme of the transforming influence of higher forces on the sinful person remained significant. Plots in the medieval mystery play had a static character, and a mirror-type composition: similar situations yet contrasted in content were depicted. Solovyov's play is also written by the same principles. The key motifs of the work are those of the spiritualization and salvation of man by love, the transformation of the world, the transition from the realm of everyday reality to the world of true values and vice versa, a call from another world. These motifs, characteristic of the liturgical mystery, largely determined the figurative system, the composition of the work and its poetics. The poetics of the mystery play was based on the belief that no single phenomenon of the world exists in isolation, but always in opposition to other phenomena and to oneself.

The structure of the universe was projected on the essence of man. Solovyov always emphasized the unity of the earthly and the heavenly, the beautiful and the ugly, the deeply spiritual and the insignificant, the moral and the immoral in the world and in the human character. The characters of the medieval spiritual drama were conventional figures, bearers of a certain idea, which can also be said about the characters in Solovyov's play.

At the linguistic level, the medieval mystery play, including the Russian one, was characterized by comic multilingualism. The speech of Solovyov's characters also combines "high" and "low" language. It is unpredictable, illogical, abounding with puns based on polysemy, homonymy or phonetic similarity of words. This reflects the "nonsense" and "grotesqueness" of consciousness and is a way to characterize the characters.

In general, we can say that The White Lily largely reflects the specific features of the medieval mystery play. At the same time, Solovyov's ideological and creative features were determined by the aesthetic and literary principles of the epoch, by the author's philosophical and literary views, by the desire to combine the high meaning of the Russian liturgical mystery play with the poetics of the late Western European examples of this genre.

\section{References}

1. Velichko, V.L. (1991) Vladimir Solov'ev: Zhizn' i tvoreniya [Vladimir Solovyov: Life and works]. In: Averina, B. \& Bazanova, D. Kniga o Vladimire Solov'eve [A book about Vladimir Solovyov]. Moscow: Sovetskiy pisatel'.

2. Solov'ev, S.M. (1997) Vladimir Solov'ev: Zhizn'i tvorcheskaya evolyutsiya [Vladimir Solovyov: Life and creative evolution]. Moscow: Respublika.

3. Bulgakov, S.N. (1996) Tikhie dumy [Quiet thoughts]. Moscow: Respublika. pp. 51-82.

4. Yurina, N.G. (2014) Rethinking of old Russian literature genre traditions in the poetic works of V.S. Solovyov. Vestnik Tomskogo gosudarstvennogo universiteta. Filologiya Tomsk State University Journal of Philology. 4 (30). pp. 135-145. (In Russian). DOI: $10.17223 / 19986645 / 30 / 10$ 
5. Radlov, E.L. (1909) Pis'ma Vladimira Sergeevicha Solov'eva [Letters of Vladimir Solovyov]. Vol. 2. St. Petersburg: Obshchestvennaya pol'za.

6. Mints, Z.G. (1974) Vladimir Solov'ev - poet [Vladimir Solovyov, a poet]. In: Solov'ev, V.S. Stikhotvoreniya $i$ shutochnye p'esy [Poems and comic plays]. Leningrad: Sov. pisatel'.

7. Rodnyanskaya, I. (2002) "Belaya Liliya" kak obrazets misterii-buff ["The White Lily" as a model of a buff mystery play]. Voprosy literatury. 3. pp. 86-102.

8. Shevchenko, E.S. (2010) Estetika balagana v russkoy dramaturgii 1900-kh - 1930-kh godov [Aesthetics of the low farce in the Russian drama of the 1900s-1930s]. Abstract of Philology Dr. Diss. Samara.

9. Odesskiy, M.P. (2004) Poetika russkoy dramy: vtoraya polovina XVII - pervaya tret' $X V I I I v$. [Poetics of Russian drama: the second half of the seventeenth century - the first third of the eighteenth century]. Moscow: RSUH.

10. Solov'ev, V.S. (1974) Stikhotvoreniya i shutochnye p'esy [Poems and comic plays]. Leningrad: Sov. pisatel'.

11. Solov'ev, V.S. (1991) Filosofiya iskusstva i literaturnaya kritika [Philosophy of art and literary criticism]. Moscow: Iskusstvo. pp. 583-605.

12. Rostovskiy, D. (2012) Uspenskaya drama [Assumption drama]. Moscow: Kniga po Trebovaniyu. [Online] Available from: http://static.my-shop.ru/product/pdf/127/1260535.pdf. (Accessed: 01.03.2018).

13. Yurina, N.G. (2010) Istoriya drevnerusskoy literatury [The history of old Russian literature]. Saransk: Mordovia State University.

14. Dashevskaya, O.A. (2005) "Belaya Liliya" Solov'eva kak misteriya spaseniya: k voprosu ob istokakh "misterial'nogo syuzheta" v literature pervoy poloviny XX veka ["The White Lily" by Solovyov as a mystery of salvation: on the origins of the "mystery plot" in the literature of the first half of the twentieth century]. In: Tashlykov, S.A. (ed.) Sud'ba zhanra v literaturnom protsesse [Fate of the genre in the literary process]. Irkutsk: Irkutsk State University.

15. Solov'ev, V.S. (1876) Sofiya [Sofia]. [Online] Available from: http://mirosvet.narod.ru/sol/sofl.htm. (Accessed: 28.07.2016).

16. Koroleva, N.V. (1967) Kommentariy [Commentary]. In: Kyukhel'beker, V.K. Izbr. proizv.: $v 2 t$. [Selected works: In 2 vols]. Vol. 2. Moscow; Leningrad: Sovetskiy pisatel'.

17. Yurina, N.G. (2014) The genre structure of V.I. Solovyov's facetious lyrics. Vestnik Leningradskogo gosudarstvennogo universiteta im. A.S. Pushkina - Vestnik of Pushkin Leningrad State University. 1 (1). pp. 30-39. (In Russian).

18. Solov'ev, V.S. (1990) Literaturnaya kritika [Literary criticism]. Moscow: Sovremennik. pp. 274-291. 